\title{
Lise Kvande
}

Førsteamanuensis ved Program for lcerarutdanning,

Noregs teknisk-naturvitskaplege universitet

Bengt Schüllerqvist (ed.):

Patterns of Research in Civics, History, Geography and Religious Education

\section{Bokmelding}

Bengt Schüllerqvist (ed.):

Patterns of Research in Civics, History, Geography and

Religious Education. Key presentations and responses from an international conference at Karlstad University, Sweden 2010

Studier i de samhällsvetenskapliga ämnenas didaktik nr 14

Karlstad: Karlstad University Press, 2011

184 sider

ISBN: 978-91-86637-03-3

Denne antologien er gjeven ut på grunnlag av ein konferanse som vart halden ved Centrum för de samhällsvetenskapliga ämnenas didaktik (CSD) i Karlstad

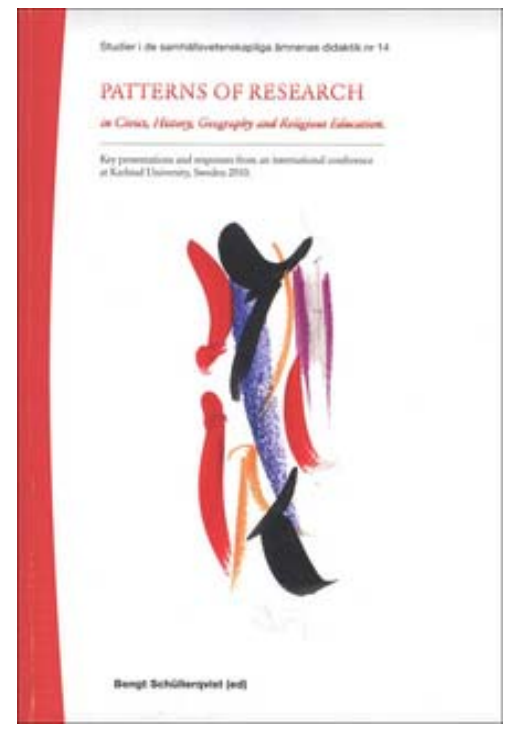
seinhausten 2010. Føremålet med konferansen og antologien er å samanlikne fagdidaktikk innanfor samfunnsfaga i dobbel tyding: For det første å samanlikne kva perspektiv og forskingsspørsmål som kjenneteiknar kvar av dei fire samfunnsfagdidaktikkane. For det andre å samanlikne korleis sentrale fagdidaktiske spørsmål ser ut frå ulike nasjonale perspektiv både i Norden og nokre andre europeiske land. Resultatet har vorte ei fagleg interessant bok som gjev oversikt over status i samfunnsfagdidaktisk forsking i dag, først og fremst i Skandinavia.

Som i fleire andre land, har også Sverige eit samfunnsfag i skulen som kombinerer fleire vitskapsdisiplinar. I tillegg til dei vi har i Noreg (historie, geografi, samfunnskunnskap), er også religionskunnskap inkludert i det svenske samfunnsfaget. Antologien tek opp alle desse fire etter tur, med ei hovudinnleiing og 2-3 kommentarinnlegg under kvar fagbolk. I eit kort innleiingskapittel gjer redaktør og leiar for CSD, Bengt Schüllerqvist, greie for ambisjonane om å samle alle fire fag til ein sams konferanse: Dei ønskte å finne ut kva spørsmål og perspektiv som står i fokus innanfor kvart av desse fire forskingsfelta, og å sjå på likskapar og skilnader mellom dei. Vidare spurde dei om metodologiske problem knytt til samanlikning av undervisning og læring mellom ulike land, og om forskarane gav råd til lærarane innanfor sine respektive felt. Hovudfokuset ligg på det første spørsmålet, og det er også det tittelen Patterns of Research viser til.

Å skulle samanlikne fagdidaktiske mønster mellom fire ulike fagretningar, er eit ambisiøst prosjekt. Det er like fullt eit prisverdig føremål, først og fremst av 
to årsaker: For det første fordi skulefaget er eitt sjølv om fagfelta er fleire. Fagdidaktikken innanfor kvart av dei fire felta har hovudsakleg vakse fram på grunnlag av fagdisiplinane og ikkje skulefaget. Spørsmålet er om det er med på å fragmentere samfunnsfaget meir enn naudsynt. Alle fagretningane som utgjer samfunnsfaget har breie og ambisiøse læreplanar samstundes som fagleg kunnskap er viktig for dei alle. Ei sterkare integrering og samkøyring av fagdidaktikkane i samfunnsfag kan såleis vere viktig sett frå eit skuleperspektiv. For det andre kan denne tverrfaglege ambisjonen vere med på å styrkje fagdidaktikken meir allment, og såleis utfordre allmennpedagogikken som eit minste felles multiplum for undervisning og læring. Kunnskap og kunnskapsformidling er kanskje først av alt både konkret og fagspesifikk, og med dette utgangspunktet kan ein fagdidaktikk på tvers fungere som ei fagleg naudsynt motvekt mot dei allmennpedagogiske perspektiva som elles har eit grundig fotfeste i skuleforsking og lærarutdanning. Som Schnak seier, handlar didaktikk om "en optagethed af noget, nemlig det forhold, at undervisning og læring altid er om noget. Man kan ikke undervise uden at undervise i og om noget, og man kan ikke bare lære, man vil altid lære noget” (Schnak 2007).

Denne artikkelsamlinga inneheld ti kapittel i tillegg til ei kort innleiing. Fordelinga mellom dei ulike fagfelta er relativt lik. I det følgjande vil hovudbodskapet og -diskusjonen frå kvart fagfelt bli summarisk presentert.

Samfunnskunnskapsdidaktikk: "Politische Bildung”. Politisk danning i tysk skule dannar grunnlaget for kapitla om samfunnskunnskapsdidaktikk. Joachim Detjen (Ingolstadt) innleier om den historiske utviklinga av dette emnet, skildrar statusen i dag både fagleg og organisatorisk og gjev eit visst oversyn over forskingsstatus innanfor samfunnskunnskapsdidaktikken. Skildringa av den tyske tradisjonen og fagstatusen ser ut til å vere lik den skandinaviske på mange punkt, men her er også skilnader. I Tyskland ligg ansvaret for skule og læreplanar til kvar delstat. Kombinert med lite samfunnsfagdidaktisk forsking, gjer det at oversikta frå Tyskland blir gjeven på eit ganske generelt nivå. Dei ulike delstatane har ikkje ein gong same namn på faget som skal gje politisk danning. Detjen skildrar korleis hovudvekta i tysk skule blir lagt på faktakunnskap om valsystem og dei demokratiske institusjonane. Læreplanane har skifta tyngdepunkt frå detaljerte instruksjonar til kompetansemål som skal kunne målast gjennom prøver, altså ei dreiing over mot resultat-kontroll (frå input til output). Detjen er sjølv involvert i dette arbeidet.

Theo Koritzinsky er den første kommentatoren til Detjen sin presentasjon, og han problematiserer ei rad av dei didaktiske vurderingane til Detjen. Kapitlet samanliknar skilnadene i tysk og norsk samfunnsfag, men poengterer at faget ikkje kan sjåast lausrive frå historie og kultur. Det gjer samanlikningar vanskeleg. Koritzinsky føreslår likevel eit komparativt forskingsprosjekt: Med utgangspunkt i dei internasjonale civics-undersøkingane (sjå t.d. Mikkelsen mfl, 2011) kan ein finne ut kva ulike grupper legg i sentrale konsept som sosial, 
offentleg, politikk, makt, styresmakter, stat, demokrati, menneskerettar m.m. ettersom dei nemnte undersøkingane ikkje i tilstrekkeleg grad tek høgde for at dei har ulik tyding i ulike kontekstar (s. 28).

Samfunnsfag i Noreg og Tyskland skal lære elevane både om og for demokrati. Likevel blir undervisninga i båe landa lagt opp slik at det er den reine faktakunnskapen som hovudsakleg blir formidla. Koritzinsky bruker dette poenget til å kritisere overgangen frå konkrete undervisningsføremål til reine kompetansemål i læreplanane. Særleg i samfunnsfag er det ikkje alt som er eigna til å bli testa som oppnådde kompetansemål, skriv han, og det gjer overgangen til resultatkontroll i undervisninga problematisk. Det som i ettertid er interessant med denne disputten, er å sjå problemstillinga opp imot arbeidet Utdanningsdirektoratet no har sett i gang for å utvikle såkalla karakterstøttande prøver i samfunnsfag for 10. klassesteget. Dei første prøvene vil liggje føre i 2013. Emnet er neppe utdebattert!

Torben Spanget Christensen (Odense) har eit anna utgangspunkt for kommentarkapitlet sitt, og det er det seinmoderne samfunnet. Detjen skildra politisk danning som eit spørsmål om "political maturity", der svara er politisk kunnskap, evne til politisk vurdering og deltaking, og ei kjensle av samfunnsansvar (s. 21f). Christensen meiner at desse elementa manglar eit vesentleg element knytt til dagens samfunn, og det er "empowerment" som kanskje best kan oversetjast med myndiggjering. Denne myndiggjeringa handlar m.a. om individuell evne til å reflektere over seg sjølv som både medborgar innanfor staten og som eit fritt, kritisk individ på arenaer dels utanfor statleg kontroll (som t.d. internasjonale friviljuge organisasjonar og sosiale medium). Her diskuterer Christensen motsetnaden mellom oppseding av lydige versus kritiske samfunnsborgarar, som Koritzinsky også har teke opp til drøfting (Koritzinsky, 2006). Denne myndiggjeringa er, i følgje Christensen, ei sams utfordring for samfunnsfaget i alle vestlege demokrati.

Samfunnskunnskap er kanskje det området som har ein minst utvikla fagdidaktikk. Desse kapitla illustrerer framfor alt korleis fagfeltet er nært knytt til både historiske og geografiske tilhøve og såleis er knytt til dei andre fagfelta i dobbel forstand. Spørsmålet er om samfunnskunnskapen kan seiast å ha eit eineansvar for den politiske danninga i skulen. Koritzinsky peikar på at det hovudsakleg er under samfunnskunnskap kompetansemåla på dette området ligg (s. 33), medan Christensen viser at samfunnsfag er bygd opp med veike skilje mellom fagfelta. Dette spørsmålet hadde det vore interessant å diskutere vidare.

Historiedidaktikk: "Interpretations of History". Dei tre kapitla om historiedidaktikk tek utgangspunkt i engelske, kanadiske og svenske (dels nordiske) røynsler etter tur. Det første kapitlet på dette fagfeltet er skrive av Christine Counsell (Cambridge, UK), mangeårig redaktør av tidsskriftet Teaching History. Til liks med kapitla føre skriv ho om læreplanarbeid, men ho gjer det frå eit lærarperspektiv. Etter krisa i historiefaget i England sist på 1960-talet, og 
igangsetjing av prosjektet "the Schools Council History Project” i 1972, har historielærarane sjølve i stor grad hatt eit grep om utvikling av både læreplanar og teoriar om historieundervisning. Det førte i første omgang til eit skifte frå fokus på historisk faktakunnskap til læring om historisk metode og konstruksjon av slik kunnskap, med andre ord ein overgang frå fakta- til prosessorientert undervisning. I neste omgang kom læreplanar som la større vekt på historisk tolking og forståing gjennom bruk av såkalla second order concepts, som m.a. årsak, verknad, signifikans, likskap, skilnad, endring, kontinuitet. Historisk tolking er det som liknar mest på den skandinaviske tenkinga kring historiemedvit, seier Counsell (s. 70), og det er interessant å sjå korleis historiebruken i samfunnet vart inkludert som ein viktig del av læreplanen frå 1990. Her er det altså snakk om ei dreiing over frå historisk metode til tolking av korleis ikkje berre ein sjølv, men også samfunnet elles på ulike nivå gjer bruk av og tolkar historie.

Counsell skildrar desse endringane og dei til dels store utfordringane det førte til for lærarane. Dei britiske røynslene er blitt følgd med interesse frå mange land, og Counsell understrekar at det er vel så mykje å lære av alle feila som vart gjort dei første åra, som av resultatet. Mellom anna tidsskriftet Teaching History er ei god kjelde her. Eit hovudpoeng for Counsell er nemleg at berre lærarane kan fortelje kva som fungerer og ikkje, og berre lærarar kan skrive ein læreplan som skal fungere. Artikkelen hennar har ei litteraturliste på ni sider, så her er mange tilvisingar for vidare lesnad.

Stéphane Lévesque (Ottawa) presenterer nokre røynsler frå utvikling av historiedidaktikken i Canada, men bruker mesteparten av kapitlet sitt til å drøfte historiemedvit, historisk tenking og kva det er viktigast å lære elevane. Kapitlet gjev ein kortversjon av boka Thinking Historically (Lévesque, 2008). Læreplanane i Canada er eit delstatsansvar så ein gjennomgang av kva som faktisk blir undervist i landet under eitt, blir vanskeleg. Lévesque skriv om eit vendepunkt i 1990-åra, då sterke krefter kravde at historiefaget på nytt måtte skape eit kollektivt minne og nasjonal identitet i det fleirkulturelle Canada.

Lévesque skriv også innanfor tradisjonen frå den angloamerikanske historiedidaktikken, og legg vekt på at kompetanse i historie først og fremst handlar om å utvikle evna til kritisk historisk tenking basert på kompetanse frå vitskapsfaget historie. Doing history er difor like sentralt for han og kanadisk historiedidaktikk som det er for Counsell og britane utan at han går nærare inn på kva det vil seie i praksis. I høve til tidlegare kapittel i boka, er det særleg interessant å sjå korleis Lévesque sine tankar om historisk tenking ligg nær Christensen sine perspektiv på myndiggjering.

Bengt Schüllerqvist (Karlstad) gjev til slutt ein særs kort historiografi over fagfeltet i Sverige og Norden, der han peikar på to endringar sidan 1980-talet. For det første at dansk historiedidaktikk ikkje lenger er like dominerande i nordisk samanheng, og for det andre at den tyske tradisjonen knytt til historiemedvit har vorte utfordra av eit større fokus på det britiske "doing 
history” (jf. Lund, 2011). Som Schüllerqvist skriv, kan det sjå ut til at dei to forskingstradisjonane let seg kombinere i praktisk historieundervisning (jf Olofsson 2011, Kvande og Naastad, 2011). Mange historiedidaktiske forskingsprosjekt er under arbeid no som er nærare knytt til praksisfeltet enn tidlegare, ikkje minst gjennom forskarskulen i Karlstad og nye mastergradsstudium i Noreg. Dermed er det grunn til å tru at den tradisjonelle dikotomien mellom tysk og britisk historiedidaktikk vil bli mjuka opp i åra som kjem.

Geografididaktikk: "Regions, Themes - international Comparisons" . Kanskje ikkje overraskande, er det geografane i denne antologien som har størst fokus på samanlikningar av undervisning mellom ulike land. Hovudinnleiar Hartwig Haubrich (Freiburg) presenterer internasjonale perspektiv på geografiundervisning frå 1970 til i dag. Grunnlagsmaterialet er to bøker om internasjonale trendar i geografiundervisning frå 1980-talet og undersøkingar som Haubrich sjølv gjennomførte i 1995 og 2005 med spørjeskjema til kolleger frå mange land. Det vil seie at Haubrich har særs mange data å presentere, og han deler inn geografiundervisninga i mange underkategoriar. Det vil føre for langt å gje ei nærare presentasjon her. Konklusjonen hans er at det er til dels særs store skilnader i føremål og undervisning i faget kringom i verda. Regionbasert undervisning står sterkt i særs mange læreplanar, endå sterkare i 2005 enn i 1995, sjølv om konseptuell eller temabasert undervisning eller ein kombinasjon også finst. Styrking av nasjonal identitet ser ut til å vere eit sentralt element for geografiundervisning i mange land, langt sterkare enn t.d. regional identitet. Haubrich avsluttar med mottoet "Find your own way by knowing what is going on internationally".

Sirpa Tani (Helsinki) kommenterer Haubrich sitt materiale ved å skildre røynsler frå eit internasjonalt prosjekt der målet var å samanlikne urban geografi i fire land. Kapitlet handlar om metodiske fallgruver og utfordringar, m.a. knytt til kontekstuelle faktorar som skulesystem, læreplanoppbygging og faget sin status i skulen, som er vanskeleg å samanlikne. Språkskilnader utfordrar samanlikning av lærebøker, og ein freistnad på å plukke ut skular i og utanfor byar i ulike land kan vise seg å ikkje vere eit signifikant skilje for komparativ analyse, skriv ho (s. 126). Tani bruker desse røynslene til å konkludere med at grundige metodiske vurderingar bør gjerast for å sikre reliabiliteten ved data samla for å samanlikne. Samstundes oppmodar ho til vidare internasjonal komparativ forsking på spørsmål som undervisning for bærekraftig utvikling, globalisering og interkulturell forståing.

Lena Molin (Uppsala) har ein kommentar til Haubrich som understrekar at nasjonal identitet og kjennskap til eige land har vore essensen i geografiundervisning, også i Sverige, sjølv om læreplanen frå 1994 ikkje støtta opp om dette perspektivet. Tradisjon og kompetansenivå hjå lærarane gjer at dei politiske intensjonane ikkje alltid blir følgd opp i klasserommet, seier ho, og byggjer såleis opp om eit poeng Koritzinsky også tek opp (s.134). Molin er ansvarleg for 
ny svensk læreplan i geografi som gjeld frå hausten 2011. Ho vil utfordre essensialismen i faget og det pedagogiske prinsippet om å gå frå det nære til det fjerne i geografiundervisninga. Kva som er nært og fjernt for elevar er ikkje lenger like opplagt i dei fleirkulturelle klasseromma. Montessori-prinsippet om å gå frå heilskap til detaljar kan vere meir fruktbart. Faget må også ta moralske spørsmål meir på alvor, meiner Molin. Fire føremål ligg i den nye læreplanen: Geografi som vitskap kombinert med verdiar; geografi for bærekraftig utvikling og for kvardagslivet, og geografi som fag for å forstå seg sjølv. Men som Molin sjølv viser, er det ikkje alltid at nye læreplanar får store utslag for korleis undervisninga faktisk blir gjennomført.

Siste geografi-kommentar er skriven av Per Jarle Sætre (Sogndal). Med utgangspunkt i si eiga doktoravhandling (Sætre, 2009) gjev han eit overblikk over geografibøker brukt i ungdomsskulane i Norden minus Island. Sjølv om læreplanar og innplassering av faget er ulikt mellom landa, er lærebøkene relativt like. Sætre deler innhaldet i tre kategoriar; regional/systematisk geografi, naturgeografi og samfunnsgeografi. At det ikkje er store skilnader mellom bøkene frå dei ulike landa, meiner han kjem av ein lang og felles fagtradisjon.

Geografi er kanskje det fagområdet som framstår som mest fragmentert av dei fire. Samstundes er det også innbakt i kvar av dei andre: Det er vanskeleg å tenkje seg samfunnskunnskap, historie og religion utan stadsdimensjonen. Det tradisjonelle fokuset på geografisk inndeling, framfor ei tematisk, kunne vore problematisert ytterlegare. Eit geografisk (romleg) utgangspunkt kan føre til identitet og samkjensle, men det kan vel også føre til respekt for pluralitet?

Religionsdidaktikk: "The interpretive Approach". Robert Jackson (Warwick) innleier denne bolken med eit kapittel om religionsundervisninga i offentlege skular i England og Wales. Emnet for kapitlet er ein metodologi for fortolkande tilnærming til religion som er utvikla av Jackson og seinare teken i bruk både av Europarådet og i fleire land, m.a. Noreg (Jackson, 1997). Religionar blir her sett på som dynamiske og heterogene og eit resultat av relasjonar snarare enn som faste og einsarta trussystem. Metodane har eit hermeneutisk utgangspunkt og legg vekt på å utvikle personleg engasjement, evne til refleksjon og refleksivitet i høve til møtet med "andre". Jackson skildrar den forskingsbaserte utviklinga av denne tilnærminga og drøftar problemstillingar knytt til representasjon, tolking, refleksivitet, "edification" og kritisk tenking. Han drøftar vidare korleis religionsfaget må vere ikkje-essensialistisk utan å ende i rein relativisme. Metodologien har også vist seg eigna til bruk i demokratiopplæring og interkulturell læring meir generelt, skriv Jackson.

Sissel Lied (Hamar) kommenterer denne metodologien på to punkt. Først i høve til menneskerettane, med bakgrunn i KRL-faget der Noreg vart dømt av menneskerettsdomstolen i 2007 for at faget ikkje var objektivt, pluralistisk og kritisk nok. Lied viser til at foreldrar har vidt ulike forventningar til kva religionsfaget skal vere og ikkje vere og at dette kan vere problematisk. Det 
andre punktet er den fortolkande tilnærminga si vektlegging av dialog i klasserommet. Ikkje alle klassar har eit klima der konstruktiv dialog er mogleg, seier Lied, og viser til eiga forsking m.a. i klasserom der religion utelukkande blir ironisert over og gjort til latter. $\AA$ skape eit trygt rom for open og fordomsfri dialog handlar ikkje berre om læraren sin evne til å disiplinere elevane; det ligg eit didaktisk element i sjølve måten religion blir forstått og omtalt på, seier Lied.

Det siste kapitlet er skrive av Geir Skeie (Stavanger/Stockholm). Han freistar å seie noko om høvet til å få til ein sams pedagogikk eller fagdidaktikk innanfor samfunnsfag og humaniora. Det har vore eit sentralt spørsmål for konferansen og antologien og passar såleis godt som ei avrunding. Skeie konkluderer med at dei ulike samfunnsfaga har mykje sams, og følgjer opp Jackson sitt bodskap om at ei fortolkande tilnærming er ein tverrfagleg utvikla metodologi som kan brukast innanfor mange undervisningsfag og -spørsmål, som t.d. interkulturell læring, demokratiopplæring og studiar av fortidige hendingar. Vektlegginga av refleksivitet og elevane sine (for)forståingar av eit gjeve emne er heilt sentralt i alle samfunnsfaga, seier Skeie, og understrekar at danningsaspektet er sentralt innanfor kvart av desse faga.

Religionsfaget har vorte stendig mindre viktig gjennom mange tiår parallelt med sekularisering og at religiøs tru har vorte privatisert. I dag er faget i ferd med å bli langt viktigare fordi det har fått ei politisk sprengkraft som aldri før. For det første gjer det lærargjerninga meir utfordrande. For det andre er det grunn til å tru at religion på sikt også vil bli ein viktigare komponent i dei andre samfunnsfaga. Ei fersk undersøking viser t.d. at innvandrarelevar i Noreg meiner religionshistorie bør bli ein viktigare del av historiefaget (Kjellevold, 2011). Samfunnsutviklinga gjer med andre ord at også religionsdidaktikken bør diskuterast meir i samband med dei andre samfunnsfaga, også i Noreg der det utgjer eit sjølvstendig fag.

Antologien viser at samfunnsfaga har mykje sams men at det også er skilnader mellom dei. Skeie har rett i at dei alle er danningsfag. Dei ulike bidraga viser også at fagleg innhald dels er overlappande - kanskje særleg gjeld det oppseding til demokrati og til myndiggjering av kvar einskild i eit fleirkulturelt samfunn i stendig endring. Vidare viser denne boka at her finst mange kontekstuelle likskapar og sams utfordringar innan kvar fagdidaktikk. Det gjeld t.d. overgangen frå detaljerte læreplanar til resultatmåling, som skjer i fleire land og på alle fagområda. Det gjeld spørsmål om lærarane sin kompetanse og om i kva grad læreplanar blir følgd opp i klasseromma. Vi veit at læreplanar ofte ikkje blir følgde, korkje i skulen eller i lærarutdanninga (Paulssen, 2011, Rosenlund, 2011, Skjelbred, 2011). Med unnatak av dei to britiske bidraga i denne boka, er det lite som tyder på at fagdidaktisk forsking har teke sjølve læringsarenaen tilstrekkeleg på alvor gjennom empirisk forsking. Her står mykje att.

Denne boka viser m.a. at fagdidaktikarar på alle felta ser på essensialisme i kunnskaps- og læringstradisjonen som eit problem. Spørsmålet er om dis- 
kusjonar om metodologi er rett stad å byrje om ein vil knyte samfunnsfaga tettare saman, slik Skeie føreslår. Sjølv om Jackson si tilnærming både er teoretisk og epistemologisk kompleks, kan ein spørje om ikkje "the interpretive approach" fører fagdidaktikken attende til eit spørsmål om undervisningsmetodikk. Kanskje meir interessant ville det vere å sjå nærare på kva kunnskapar og verdiar som pregar kvart av fagområda, korleis desse står i høve til kvarandre og kor det eventuelt oppstår sprik eller manglar. Samfunnsfaget og alle fagfelta under det, er gjennomgåande politisk, eller verdiforankra om ein vil. Som denne boka viser, har alle fagdidaktikkane utfordringar knytt til kva kunnskapar og verdiar dei vil formidle, og alle står andsynes spørsmål om demokrati og medborgarskap, identitetsutvikling og myndiggjering, globalisering og det fleirkulturelle samfunnet. Det er prisverdig at CSD i Karlstad har gjeve ut denne antologien, og så får vi vone at diskusjonane om mønster, likskapar og skilnader i og mellom samfunnsfagdidaktikkane held fram.

\section{Referansar}

Jackson, Robert (1997). Religious Education: An interpretive Approach. London: Hodder \& Stoughton.

Kjellevold, Gisle (2011). Historie og identitet i den flerkulturelle skolen: en undersøkelse av historiens betydning for ungdomsskoleelevers identitetsdanning. Masteroppgåve i samfunnsfagdidaktikk. Trondheim: NTNU, Program for lærarutdanning.

Koritzinsky, Theo (2006). Samfunnskunnskap. Fagdidaktisk innføring. 2. utgåve. Oslo: Universitetsforlaget.

Kvande, Lise og Nils Naastad (2011). Historiedidaktiske skisser 1-2. Trondheim: NTNU, Program for lærarutdanning.

Lévesque, Stéphane (2008). Thinking historically. Educating Students for the 21st Century. Toronto: University of Toronto Press.

Lund, Erik (2011). Historiedidaktikk: en håndbok for studenter og læerere. Oslo: Universitetsforlaget, 4. Utgåve.

Mikkelsen, Rolf, Dag Fjeldstad og Dag Lauglo (2011). Morgendagens samfunnsborgere. Oslo: UiO, Acta Didactica Oslo nr 2.

Olofsson, Hans (2011). Fatta historia. En explorativ fallstudie om historieundervisning och historiebruk i en högstadieklass. Licentiatavhandling. Karlstad: Studier i de samhällsvetenskapliga ämnenas didaktik nr 12.

Paulssen, Christian (2011). Historiebevissthet: Erfaringsnæert, men teorifjernt. En undersøkelse av undervisningsorienteringer til et utvalg historielærere i videregående skoler i Sør-Trøndelag. Masteroppgåve i samfunnsfagdidaktikk. Trondheim: NTNU, Program for lærarutdanning.

Rosenlund, David (2011). Att hantera historia med ett öga stängt. Samstämmighet mellan historia A och lärares prov och uppgifter. Lund: Malmö högskola, Forskarskolan i historia och historiedidaktik nr. 2.

Schnak, Karsten (red. 2007). Didaktik på kryds og tværs. København: Danmarks Pædagogiske Universitets Forlag.

Skjelbred, Henrik (2011). Samfunnsfagdidaktikk i lærerutdanningen. Seks lærerutdanneres syn på samfunnsfagdidaktikkens rolle i den nye grunnskolelcererutdanningen.

Masteroppgåve i samfunnsfagdidaktikk. Trondheim: NTNU, Program for lærarutdanning.

Sætre, Per Jarle (2009). Geografi i tekst og bilde. Dr.avhandling. Trondheim: NTNU, Geografisk institutt. 